\title{
Proposed Secured Bay-Salam Model for Financing Agriculture by Islamic Banks
}

\author{
Ummi Ibrahim Atah,
} Mustafa Omar Mohammed, Engku Rabiah Adawiyya, Adewale Abideen Adeyemi

International Islamic University Malaysia

\begin{abstract}
Bay Salam is a type of forward contract between two parties to sell or buy a commodity set at agreed terms and conditions on a future date. The Bay Salam contract is beneficial for both buyer and seller because the seller receives full payment in advance while the buyer pays at a favourable price. Despite its benefits to farmers and vendors, this mode of financing is widely available. Therefore, this article aims to explore the concept of the Bay Salam contract and its potential application in financing the agricultural sector in contemporary banking system. This research adopts a qualitative approach by critically reviewing the literature and conducting semi-structured interviews with seven financial and agricultural experts in Nigeria using purposive sampling method. Findings show that Bay Salam is largely unpopular in modern days due to high level of risk and management responsibilities required for the financier. The novelty of this paper lies in the proposed model which combines the concept of Bay Salam and Takaful.
\end{abstract}

Keywords: Bay Salam, Agricultural Insurance, Agriculture Financing, Takaful, Islamic Banks, Islamic Financial Institutions

Received: 13 March 2019

ISSN 2056-757X

Revised: 10 July2019

Accepted: 30 Sept 2019

https://doi.org/10.18646/2056.64.19-013 


\section{Introduction}

Agriculture is facing various challenges in meeting global demand for food due to growing world population and climate change. Notwithstanding increased political support, financial support for farmers and agribusinesses remains limited especially in developing countries. World Bank (2018) identified the constraints faced by financial institutes as follow: 1) high transaction costs involved in reaching rural farmers; 2) high risk; 3) inadequate instruments to manage risk; 4) lack of expertise in managing agricultural loan portfolios; and 5) ineffective policies. Similarly, Sadler et al. (2016) summarised three main barriers to lending: high transaction cost, inadequate enabling environment, and agricultural risk. A closer examination of these challenges highlights the risky nature of agricultural financing as it is subject to price volatility. Due to the long-term nature of farming and the perishable nature of agricultural products, food supply is unable adapt quickly (Sadler et al., 2016). In the case of overproduction, farmers are forced to make substantial changes in pricing to sell their agricultural products. Natural factors such as pests, diseases, and adverse weather conditions can have huge impact on agricultural output. In addition to low production responsiveness, macro-economic factors; namely oil prices and exchange rates, also affect food prices (Tropea and Devuyst, 2016). A lack of policy support and high transaction cost also discourage financiers from lending to farmers and also create barriers to financing agriculture (Sadler et al., 2016). In short, agriculture financing has a low return on investment and high risk.

Farmers and small agribusinesses in developing countries often experience difficulty in accessing finance. Partly, this is due to their socio-economic status leading to them being characterised as un-bankable people (Moh'd et al., 2017; Muneeza et al., 2011; Saiti et al., 2018). Moreover, farmers are required to pledge collateral and prepare feasible business plans when applying for funding (Cabannes, 2012; Moh'd et al., 2017; Sadler et al., 2016). For urban farmers, it is quite difficult to translate ideas into sound financial terms to enable bankers to approve funding (Cabannes, 2012). This level of difficulty is greater in developing countries with low literacy rates. In turn, financial institutions charge the applicants higher interest rates and there are punitive responses to default (Cabannes, 2012) together with numerous banking restrictions such as mandatory lending quotas (Sadler et al., 2016).

Taking these factors together, there is a need for an alternative agriculture financing which is cost-effective and risk-resilient. One good example is Bay Salam (forward sale agreement), an Islamic contract used to provide working capital to the finance seeker on terms compliant with Shariah (or Islamic law). Unlike other types of forward contract, in Bay Salam transactions full payment is made in advance, thereby allowing farmers to purchase necessary tools and equipment. In return for the added risk of advance payment, the buyer pays a favourable price for the commodity.

This paper explores the viability and feasibility of Bay Salam as an alternative mode of agriculture financing. In the course of accomplishing the research aim, the underlying concept and controversies revolving around Bay Salam will be discussed, together with the agricultural insurance available in the market. The main focus is to identify possible ways to mitigate risks incurred in agriculture financing and while at the same time being in accordance with the rules of Shariah.

International Journal of Management and Applied Research, 2019, Vol. 6, No. 4 


\section{Islamic Finance and the Concept of Bay-Salam}

At the core of Islamic finance is an understanding of the avoidance of riba (interest) and gharar (uncertainty). Islamic law considers lending with interest payment as exploitative and the practice of earning interest is prohibited under Islamic law. The concept of gharar is of equal importance; under Islamic law, there are strict rules against transactions that are risky, highly uncertain or contracts that are not drawn out in clear terms. Under Islamic law, it is not permitted to sell a commodity which is not in the possession of the seller and the commodity must exist at the time of signing the contract. Bay Salam is a forward contract which is permitted as an exceptional case by Prophet Muhammad (peace be upon him) and the later jurists (Zaman, 1991). The rationale behind this was the difficulty faced by the farmers in securing finance (Muneeza et al., 2011; Zaman, 1991).

According to Zaman (1991), the practice of Bay Salam was prevalent in Madinah even before the advent of the Prophet Muhammad (peace be upon him). When asked for guidance by his Madinan Companions, the Prophet approved it under certain conditions. These conditions were further expanded by later jurists. These conditions include the following:

- First, the buyer must pay full payment at the time of making the contract.

- Second, the commodity must not be in the nature of money.

- Third, the buyer must clearly define the quality and the quantity of the commodity before a contract is made.

- Fourth, the time of delivery of the commodity must be specified.

- Fifth, the commodity must be readily available at the time of delivery.

Table 1 summarises the differences between Bay Salam and a typical forward contract.

Table 1: Differences between Forward Contract and Bay Salam

\begin{tabular}{lll}
\hline & Forward contract & Bay Salam contract \\
\hline $\begin{array}{l}\text { Payment } \\
\text { Time of payment }\end{array}$ & Flexible; customisable & Full payment \\
Commodity & Deferred payment & Advance payment \\
& No restriction & Restricted to agricultural \\
& & products, raw materials, and \\
Risk & fungible goods
\end{tabular}

\subsection{The Economic Significance of Bay Salam}

To a great extent, Bay Salam serves the interest of farmers well, for three main reasons: first, it eliminates the need for interest repayment; second, it allows the farmer to cover daily expenses and purchase necessary raw materials and tools, third, it eliminates risk in marketing and selling agricultural products (Zaman, 1991). The buyer, on the other hand, benefits from the low price of the commodity (Kaleem and Wajib, 2009; Kaleem and Ahmad, 2010; Muneeza et al., 2011).

At the national level, Bay Salam would maintain a minimum level of production. Bay Salam could be an effective means of stabilising market prices because resale of the Bay Salam commodity before delivery is not permitted under Islamic law,

International Journal of Management and Applied Research, 2019, Vol. 6, No. 4 
thereby avoiding speculative price rises (Zaman, 1991). The principles of Islamic finance place weight on investment in the real economy (Abdul-Baki and Uthman, 2017), suggesting that Islamic banking and finance is likely to prevent technical speculations and economic bubbles.

Despite the economic significance of the Bay Salam contract, it is largely unpopular in many countries, mainly due to its high risk nature from the financier's perspective.

\subsection{The Role of the Islamic Bank in Bay Salam Contract}

Traditionally, the buyer (or financier) in a Bay Salam contract used to be a trader, consumer, friend, or relative (Zaman, 1991). In modern times, however, the role of the bank in Bay Salam transactions is quite complicated. Zaman (1991: 452) claims that the "purchase of a commodity does not necessarily serve the interest of the bank nor is it always a profitable proposition for it". Besides transporting and storing the commodity safely, the bank also needs to find buyers (Muneeza et al., 2011), which goes above and beyond the duties and obligations of a typical bank. Moreover, the bank "has to discharge a financial obligation of national economy" (Zaman, 1991: $450)$ if it offers Bay Salam contracts for farmers on a large scale. Kaleem and Wajib (2009) suggest that parallel salam can eliminate the problem of dealing with a commodity because it acts as an intermediary between buyer and seller, allowing the bank to enter into two separate contracts: first with the seller (the farmer) and second with the buyer (consumer or middleman). However, the bank bears the risk of nondelivery if the farmer is unable to deliver the commodity on time and is thus liable for breaching the second contract (Muneeza et al., 2011).

Despite the bank having the right to obtain collateral, guarantee or security from the seller (Kaleem and Wajib, 2009; Kaleem and Ahmad, 2010; Muneeza et al., 2011), the bank is exposed to a high degree of risk in the case of default. Unlike in forward contracts where the risk of non-delivery is shared by both parties, the risk is borne by the financier alone in the Bay Salam contract. Since full payment is made in advance, the financier would bear any potential loss in the case of fluctuations in commodity prices (Kaleem and Wajib, 2009; Kaleem and Ahmad, 2010; Saiti et al., 2018).

Because of the above mentioned reasons, Islamic financial institutions (IFIs) are reluctant to adopt Bay Salam (Muneeza et al., 2011) and consider it to be the least favoured mode of financing (Saiti et al., 2018).

\section{Agricultural Insurance and the Concept of Takaful}

Agricultural insurance is designed to cushion farmers against loss of crops due to adverse weather or financial loss due to price volatility. Agricultural insurance is not only limited to crops but is also applicable to livestock.

Despite agricultural insurance being a commercial activity, it is not uncommon to see public intervention to helping farmers to safeguard their livestock and crops. In a study of government support to agricultural insurance, two-thirds of the countries surveyed were found to have public intervention in agricultural insurance whereby the government provides premium subsidies to farmers and agribusinesses (Mahul and

International Journal of Management and Applied Research, 2019, Vol. 6, No. 4 
Stutley, 2010). The study was based on a survey conducted by World Bank in 2008, aimed at analysing trends and developments in agricultural insurance programs in 65 countries. Mahul and Stutley (2010) also mentioned that there was a growth in public sector insurance schemes between 1950s and 1980s; however, most of these schemes were terminated due to poor management.

Agricultural insurance is compulsory for agricultural loans in developing countries (Mahul and Stutley, 2010). However, the potential clients in the least developed countries are mostly illiterate and thus may not aware of insurance; there are also other barriers such as lack of affordability and limited access to insurance programmes (Htay et al., 2015; Johnson et al., 2018; Mahul and Stutley, 2010). For many low-income farmers, agricultural insurance is a low priority (Mahul and Stutley, 2010).

Much of the agricultural insurance available in the market is not Shariah compliant and is thus inaccessible to Muslim pastoralists. Islam encourages its followers to anticipate any possible negative occurrences and to take precautions to mitigate them (Mahmood, 1991). Takaful is a form of insurance based on Islamic law, which encourages mutual assistance (Ali and Nisar, 2016; Htay et al., 2015; Mahmood, 1991; Maysami and Williams, 2006). Instead of paying premiums as in conventional insurance, all members in a Takaful arrangement contribute money to a common pool to guarantee each other against damage or loss (Htay et al., 2015). The Takaful fund may be invested in any Shariah compliant investments and any profit generated from the investment will be credited back to the fund (Htay et al., 2015; Kassim, 2013; Maysami and Williams, 2006). Any claims made by the members are paid out of the Takaful fund (Ali and Nisar, 2016). In the event of a deficit in the Takaful pool, the Takaful operator is obliged to ensure the solvency of the Takaful by providing an interest-free loan, the loan to be repaid when the pool has a net surplus (Kassim, 2013).

There are a number of Takaful schemes covering agricultural products. Established in 1983, Shiekan Insurance and Reinsurance is the largest Takaful operator in Sudan; the company provides a wide range of Takaful products, including agricultural insurance launched in 2002 (Leading Edge, 2016). In 2014, a Kenyan Takaful company launched Index-Based Livestock, a Shariah compliant index product that provides cover against drought; however, two years after the launch, the company has been experiencing similar operational challenges and pressures from investors to the conventional insurance model (Johnson et al., 2018).

Htay et al. (2015) claimed that Takaful operators tend to offer products that are affordable only to high- and middle-income groups, while the low-income group is often uninsured and missing out on the benefits of Takaful. This is particularly prominent in the least developed countries where a large percentage of the population has no financial access.

To alleviate poverty, it is important to have financial programmes that are tailored to the financial needs of low income households, especially farmers. Microfinance has been proven effective in creating opportunities for self-employment (Jia et al., 2013) and alleviating poverty (Manap et al., 2017). Equally, micro-insurance has received growing attention from the industry experts (Mahul and Stutley, 2010), scholars (Htay et al., 2015) and, most importantly, people in need (Gessesse, 2019). It is now time to

International Journal of Management and Applied Research, 2019, Vol. 6, No. 4 
progress further and consider alternative modes of financing that are in accordance with the principles of Islamic law.

\section{Shariah-Compliant Agriculture Financing}

A number of scholars have proposed models of agriculture financing compliant with Shariah law. Oladokun et al. (2015) proposed the Muzara'ah supply chain model as a solution to meet the financial needs of farmers in Nigeria. Like most conventional banking, agriculture financing in Nigeria involves high interest charges, collateral requirement, and astringent terms and conditions. Under the proposed Muzara'ah supply chain model, the financial institution acts as a partner, responsible for coordinating operations in the supply chain, which includes transportation, storage, marketing and sourcing. One major limitation to the proposed model lies in the heavyduty management responsibilities from the financier.

Muneeza et al. (2011) and Putri et al. (2019) proposed a Bay Salam hybrid model with the use of the Wakala (agency) contract. Under this model the bank provides working capital to the farmer. After the harvest, the bank appoints the farmer as an agent to sell the crops and pays agency fees to the farmer. In this way, the bank is free from managing operations in the supply chain and selling agricultural products. Arguably, however, the return on investment is low and the agricultural risk is high in this model, just as in conventional agriculture financing. In other words, there is little attraction for the bank to adopt this model.

Kaleem and Wajid (2009) proposed three models for agriculture financing, these are: agency, subsidiary, and the Musharakah model to mitigate potential risks. Unlike Muneeza et al. (2011), the agency model proposed by Kaleem and Wajid (2009) places no emphasis on the selection criteria for the agent. This means that the agent could be anyone and is not limited to farmers. Moreover, the agent enters a contract with the farmer at early stage. Under this arrangement, the bank bears less risk than in the Bay Salam contract. Likewise, the bank carries less risk in the subsidiary model, when compared to the Bay Salam contract. In the subsidiary model, a bank opens a subsidiary which is in charge of all the operations of the supply chain and the sale of agricultural products. In the Musharakah model, on the other hand, all parties are coowners of the joint asset or commodity on a pro-rata basis. After the harvest, the farmer can purchase the share of the commodity from the bank according to the agreed terms and conditions. In terms of serving the interest of the bank, these three models are more viable in comparison with the Muzara'ah supply chain model (Oladokun et al., 2015) and the Salam-Wakalah model (Muneeza et al., 2011). However, these models may not serve the interests of the farmer well because the farmer still bears any potential loss in the case of natural disaster and may not receive sufficient and timely funding.

Saiti et al. (2018) proposed a Salam-based crowdfunding structure, which involves the following parties: farmers, fund providers, a trustee, a crowdfunding operator, and Shariah experts. In this mode of financing, all risks are shared among a group of investors and a large sum of capital can be raised from the same group of investors. The presence of Shariah experts is to ensure that all activities are compliant with

International Journal of Management and Applied Research, 2019, Vol. 6, No. 4 
Shariah and the trustee is responsible for selecting suitable products that match the investment criteria. Similar to a conventional Bay Salam contract, the farmer receives advance payment in full in a Salam-based crowdfunding. Nonetheless, the investors are exposed to a high level of risk, and there is no means for them to mitigate risks of non-delivery or fiduciary risk.

To sum up, the abovementioned models of agriculture financing have their own limitations and may not be feasible in practice. This calls for a more viable mode of Shariah-compliant agriculture financing.

\section{Proposed Bay-Salam with Takaful Model}

Based on a thorough review of existing literature, it is noted here that Shariah compliant agriculture financing is not without limitations. For this reason, this paper proposes a hybrid model which combines the concept of Bay Salam and Takaful, with active involvement of farmers associations. The following steps show how the model will work in practice:

Step 1: Farmers contribute to Takaful operator.

Step 2: Farmers' association seeks financing from Islamic Financial Institution (IFI) on behalf of the farmers.

Step 3: IFI finance farmers through the association, involving the farmers' association as guarantors.

Step 4: After the harvest, farmers supply commodities to IFI through the farmers' association.

Step 5: IFI appoints the farmers' association as agent to sell commodities.

Step 6: In the case of late and poor harvest, farmers seek indemnity under the insurance policy, and the losses incurred by any Takaful participants of the pool will be compensated.

Step 7: Takaful operator compensates the IFI in the case of late or poor harvest.

First of all, the farmers put an agreed amount of money into the Takaful fund, and this allows farmers to mutually support, protect, and guarantee each other especially in the case of financial losses.

Next, the farmers' association represents farmers in negotiating a sensible financial arrangement with the IFI. The IFI assesses the financial viability of the proposal made by the farmers' association, with the help from the agricultural expert in assessing the technical aspects of the agriculture. Based on a careful analysis of productivity and return on investment, IFI makes an offer to the farmers' association. Acting as guarantor, the farmers' association reaches an agreement with the IFI, and specifies all terms and conditions in Bay Salam contract.

International Journal of Management and Applied Research, 2019, Vol. 6, No. 4 
After signing the contract, the IFI makes full payment in advance in accordance with the Bay Salam contract. Serving as a guarantor, the farmers' association monitors crop growth and provide supports to farmers if necessary. Additionally, the clusters of farmers support each other to ensure on-time delivery and continued financing of ongoing activities. The best case scenario is when the farmers are able to fulfil their contractual obligations. At this stage, the farmers' association also acts as an agent to the IFI, for the purpose of transporting, storing and selling the commodities by entering into an independent agency contract. The scope and nature of the agency contract needs to be clearly stated.

In the worst case scenario, where the farmers suffer crop losses, the farmers can seek indemnity under the insurance policy. The Takaful operator needs to investigate and verify if the farmers actually suffer any loss. If the Takaful operator conclude that the damage of loss is not caused by negligence, the farmers and IFI will be compensated.

The advantages of the proposed Bay-Salam with Takaful model are:

Firstly, it uses multiple risk management techniques, including risk-transfer and riskmitigation. While farmers transfer risk to the Takaful organisation and the IFI transfers risks to an agent, the agent takes precautions to mitigate risk. The agent, in this model refers to the farmers' association, works very closely with the IFI and farmers and thus the agent should be able to manage any problem as it arises.

Secondly, it promotes mutual support and cooperation among farmers. By putting farmers into clusters, farmers no longer compete with each other but act as a group. In this way, the farmers monitor each to ensure that commodities can be delivered on time.

Thirdly, it encourages the farmers' association to step out. In this model, farmers association not only acts as a guarantor, but also an agent. The association represents both farmers and the IFI at different stages thereby avoiding conflict of interest.

\section{Methodology}

This paper explores the viability of Bay Salam as an alternative mode of agriculture financing. Semi-structured interviews with seven experts were conducted in Kano State, Nigeria. Seven financial and agricultural experts were selected using the purposive sampling method. According to Sandelowski (1995, p.179), the "logic and power" of the various kinds of purposive sampling lie primarily in the quality of information obtained per sampling unit, as opposed to their number per se. The specific site and respondents were selected because they provided a wide spectrum of backgrounds, ranging from an expert in Takaful to a manager who works in the Islamic Bank, from the Director of Ministry of Agriculture to the Chairman of the farmers' association. The discussions with the industry experts helped to understand the understanding of industry experts towards the use of Bay Salam as a way to finance farmers. When analysing the data, thematic analysis was used due to the exploratory nature of this paper.

International Journal of Management and Applied Research, 2019, Vol. 6, No. 4 
The researcher first seeks consent from the respondents by booking an appointment to conduct the interview. Upon approval, a face-to-face semi-structured interview was conducted with the experts in their offices. In addition, the interview was conducted using a native language (Hausa). Initially, the interview questions were written in English, an expert in translation translated the English version to Hausa through backward translation. The responses were recorded by $\mathrm{mp} 3$ and tape recorder after permission was gained from the respondents. The recorded interviews were replayed at the venue of the interview to make sure that the recording could be heard clearly for data analysis. The time frame of the interview was approximately one hour.

\section{Results and Discussion}

The demographic profile of the research participants is summarised in Table 2. All respondents are male, and most of them hold executive and managerial positions. Table 2 indicates that majority of the respondents have more than ten years of experiences in their profession, and three of them have nearly thirty years of experience. The table also shows that all respondents are well-educated, as all of them attended higher education institutions.

\begin{tabular}{|c|c|c|c|c|}
\hline Code & Position & Profession & Years of experience & $\begin{array}{r}\text { Level of } \\
\text { Education }\end{array}$ \\
\hline E1 & Director of KNARDA & Agriculture & 25 years & Degree \\
\hline E2 & $\begin{array}{l}\text { Chairman of } \\
\text { farmers' association }\end{array}$ & Agriculture & 30 years & Degree \\
\hline E3 & $\begin{array}{l}\text { Director of } \\
\text { Ministry of Agriculture }\end{array}$ & Agriculture & 27 years & Master \\
\hline E4 & $\begin{array}{l}\text { Zonal manager at } \\
\text { Bank of Agriculture }\end{array}$ & Banking & 30 years & Master \\
\hline E5 & $\begin{array}{l}\text { Shariah manager at } \\
\text { Stanbic IBTC Bank }\end{array}$ & $\begin{array}{l}\text { Islamic } \\
\text { finance }\end{array}$ & $\begin{array}{r}13 \text { years in traditional bank; } \\
7 \text { years in Islamic bank }\end{array}$ & Master \\
\hline E6 & $\begin{array}{l}\text { Manager at } \\
\text { Jaiz Bank }\end{array}$ & $\begin{array}{l}\text { Islamic } \\
\text { finance }\end{array}$ & $\begin{array}{r}11 \text { years in traditional bank; } \\
7 \text { years in Islamic bank }\end{array}$ & Master \\
\hline E7 & Shariah expert & Takaful & 15 years & Master \\
\hline
\end{tabular}

The researchers coded the interview transcript into themes and sub-themes. One dominant theme (risk mitigation) and six sub-themes were identified by the researchers. These subthemes are: default risk reduction; production risk reduction; post-harvest risk reduction; market risk reduction; price risk reduction; and mutual guarantee provided by Takaful.

\subsection{Bay Salam with Takaful model can minimise risk}

All respondents agreed that the proposed model can minimise risk. As respondent five (E5) put it:

...Risk is inevitable because the hand that receives profit will also receive loss one time. Banking business by its nature is use[d] to this kind of risk. But if you are adopting this model risk is minimise[d]. This is because everything is organised and involve[s] expert advice. Therefore, experts know what crops are marketable and those that are

International Journal of Management and Applied Research, 2019, Vol. 6, No. 4 
not. The proportion of input require[d] by the farm is also known. The banks will also purchase and pay [for] the inputs directly from the input providers.

Similarly, E1, E7 and E6 stressed that the fear of financial institutions can be reduced by the proposed model.

\subsection{Default Risk Reduction}

Except for respondent E2, all respondents agreed with the view that the proposed Bay Salam model could help to reduce intentional and unintentional risk of default. Intentional or not, default is a common problem faced by all financial institutions which often discourages them to lend money to farmers. This statement is supported by all interviewees. E1 also stated that the provision of Takaful serves as a cushion against natural disaster. E4 added that farmers need to be educated about the economic implications of default for both parties and reminded about default behaviour in the eye of Allah. E7 commented that:

Eh! ... Of course there is going to be decrease in the number of risk because don't forget the default risk can be as a result of deliberate attempt by the farmer or as a result of disaster. In any case both are provided by the model because Takaful will take care of any loss that arises as a result of natural disaster. Meanwhile the deliberate default can be dealt with by given the financing through cooperative/Farmers associations, these associations will give cover by serving as grantors therefore the level of default risk will be reduce[d].

\subsection{Production Risk Reduction}

Respondents (E2, E3, E6 and E7) agreed with the view that the proposed model could minimise production risk. According to E2 and E6, the involvement of experts is an essential feature of the model which could mitigate the problem of low quality and quantity. According to E7:

The proper way of curtailing the risk issues is to have [a] plan and organize thing $[\mathrm{s}]$ as it is. You cannot use a land which is not meant for planting rice and emphasized that rice must be planted. Everything should be place[d] in order. Appropriate inputs should be used for higher return to reduce the risks of low yield. For instance, you cannot anticipate higher yield meanwhile you do not have qualitative and standard seeds and fertilizer. Even the fertilizer, there are some plants that require locally made fertilizer not factory made... There must be the involvement of [an] expert in agriculture who will monitor the management of the farm to achieve [the] desired objectives. Therefore, as the model will provide expert[s] to impart technical skills and knowhow then for sure this will reduce the risk of poor quantity and quality.

This view was also shared by other research participants, with respondent three (E3) stating that:

Insha Allah will help to reduce the level of risk, this is because the expert have the skills and knowhow therefore they have to give their

International Journal of Management and Applied Research, 2019, Vol. 6, No. 4 
expert advice to farmers and farmers are expected to abide by the professional advice of the expert. This is what is called; if your hand is dirty you have to use both hands to wash for it to be clean. If this method is adopted it will work. Of course it will reduce the production risk because involvement of expert[s] leads to success, if their advice is followed [it] leads to improvement of the produce.

\subsection{Post-harvest Risk Reduction}

Respondents (E1, E2, E7 and E5) agreed that the model, if implemented, can solve the problem of post-harvest loss. E1 and E2 think that the farmers will no longer have the problem of storage if the model is implemented. Respondent (E7) shared with the researcher that:

This model can minimise risk of low yield due to post harvest which emanated from the interrelated problem of storage and transportation, harvesting and milling of crops. This is because storage and transportation are necessary for proper delivery of crops into market after harvest. Meanwhile [the] majority of farmers lack the required resources to afford such amenities. But since financial institutions will take care of this, it means the problem is minimised to the minimum. The harvesting and milling will be rest to expert that has the adequate techniques therefore the problem is also reduced.

Respondent (E5) shared his views regarding post-harvest risk and proper measures that should be undertaken:

...from the banking side the part of risk they are concern about is from the processors (post-harvest risk) that is the farmer ...... return the crops to bank as promise but the processing firm will not process the product well and therefore damaging the crops resulting in a low price. In this instance, what I recommend ... is collateral from the processing company in case if they did not process well the bank can withhold their collateral. However, the processing equipment that the bank finances for the processor also has to be insured and must have collateral. Even if there is any calamity, it is hoped that there is [a] way out through Takaful and this will also pave way for planning ahead.

\subsection{Market Risk Reduction}

Respondents (E1, E2, E3, E4, E5 and E6) agreed that the proposed Bay Salam model could reduce the marketing risk faced by the farmers. For E3, E5, and E6, the sale is guaranteed and the farmers do not need to worry about selling and marketing their crops. Respondent two (E2) declared that:

Apart from addressing pricing risk it will bring a ready-made market for the farmer's crop because already financial institutions will be repaid in kind the issue of market risk is therefore reduce[d]. Thus, the issue of poor access to market is already null, this is quite ok as [it] will bring agricultural development...The repayment in kind will assist the farmers immensely Alhamdulillah what does the farmers needs the

International Journal of Management and Applied Research, 2019, Vol. 6, No. 4 
crops for, he plants so as to sell and so he already gets the financial institution to sale his crops.

\subsection{Price Risk Reduction}

Respondents (E1, E2, E3 and E4) agreed that the proposed model can minimise the price risk. E1, E2 and E3 said that the issue of price fluctuations will be minimised because this is taken into consideration in the agreement. In this regard E4 asserted that:

The pricing issue which seriously affects farmer's productivity is dealt with by the model by considering fluctuations in prices and setting the quantity to be supplied by the farmer in line with the price fluctuations [which] will minimise price risk and exploitation of contracting parties.

\subsection{Mutual Guarantee provided by Takaful}

All respondents agreed that the Takaful feature of the model brings a lot of benefit to the farmers. One agricultural expert (E1) noted that Takaful provide guarantees to farmers through risk-sharing, and one financial expert (E4) commented that:

The model will reduce various risks in financing agriculture because incorporating Takaful as a prerequisite condition for giving financing to farmers...will provide guarantee to banks to offer all [the] required financing facilities and hence increase access to finance to farmers.

Likewise, another financial expert (E5) explained the operational procedure of Takaful and how it can provide guarantee cover to farmers. He stated that:

....the banks they have to look at the commodity that is marketable with high demand that will command good price. So the challenge to be encountered will be small. Because the model will be organised in such a way that the agricultural expert should be involved who will make sure that the farm is manage[d] appropriately and whatever input the farm required is being provided to farm. Risk is inevitable, it can occur but since there is Takaful cover and if the risk happen to many farmers that the Takaful will not be able to cover the risk alone there are giant re-Takaful firm outside the country that can help the Takaful company. So if there is this kind of problem that re-Takaful company can assist to ensure sustainability and continuity of the financing. Therefore, the presence of Takaful in this model provides Risk measures that will ensure sustainability and continuity of the financing.

\section{Conclusion}

The article explores the concept of Bay Salam and Takaful as financial tools to meet the financial needs of farmers. This article also examines current models of Islamic agriculture financing and the literature review shows that the existing Shariah compliant agriculture financing modes are without limitations. Hence, this study proposes a hybrid model of Bay Salam and Takaful, in addition to the active participation of farmers associations and collective power. The main objectives of this proposed model are to create efficient risk management strategies and financial sustainability for both farmers and IFI.

International Journal of Management and Applied Research, 2019, Vol. 6, No. 4 
The significance of the proposed model is threefold:

First, it will help to encourage a collaborative spirit by building clusters of farmers. It is a collaborative network which consists of a variety of farmers that are geographically distributed but able to help each other when needed.

Second, it will help in reducing poverty and promote regional development. Given its emphasis on cooperation and coordination, the model can be applied on the national scale, thereby improving financial accessibility and fostering economic development.

Third, it will help IFI to accomplish and further the socio-economic goals of Islam because the proposed model is a form of socially responsible investment for IFI. At the macro level, the model could contribute to the real economy and transform many lives.

\subsection{Limitations and suggestions for further research}

To explore the perceptions of industry experts towards Bay Salam, this paper interviewed seven financial and agricultural experts. One major limitation of this research is its sample size. Future research could conduct statistical analysis to gain a more complete picture regarding the views of industry experts about Bay Salam.

This article reviews current models of Shariah compliant agriculture financing and discusses the potential of incorporating Takaful into Bay-Salam as a means to mitigate risk in financing agriculture. The proposed model is restricted to farmers only, which could be extended to other relevant sectors, such as fishery and poultry. A major constraint of the proposed model is that, it has to reach critical mass to be impactful and self-sustaining. At a minimum level, it should consist of a sufficient number of farmers to form a collective power which puts them in a strategic position in making financial arrangement with the IFI. A group of two farmers may not be able to create a collective bargaining position.

\section{References}

1. Abdul-Baki, Z. and Uthman, A. B. (2017), "Exploring the "social failures" of Islamic banks: a historical dialectics analysis", Journal of Islamic Accounting and Business Research, Vol. 8, No. 3, pp. 250-271. https://doi.org/10.1108/JIABR-062014-0021

2. Ali, S. N. and Nisar, S. (2016), Takaful and Islamic Cooperative Finance: Challenges and Opportunities. UK: Edward Elgar Publishing.

3. Cabannes, Y. (2012), "Financing urban agriculture", Environment and Urbanization, Vol. 24, No. 2, pp. 665-683. https://doi.org/10.1177/0956247812456126

4. Gessesse, A. S. (2019), "Milking it? Ethiopian farmers fight drought with insured cows", Reuters [Online] Available from: https://www.reuters.com/article/usethiopia-climatechange-insurance/milking-it-ethiopian-farmers-fight-drought-withinsured-cows-idUSKCN1ST0QE [accessed on 30 April 2019].

International Journal of Management and Applied Research, 2019, Vol. 6, No. 4 
5. Htay, S. N. N.; Sadzali, N. S. and Amin, H. (2015), "An analysis of the viability of micro health takaful in Malaysia", Qualitative Research in Financial Markets, Vol. 7, No. 1, pp. 37-71, https://doi.org/10.1108/QRFM-09-2013-0030

6. Jia, X.; Xiang, C. and Huang, J. (2013), "Microfinance, self-employment, and entrepreneurs in less developed areas of rural China", China Economic Review, Vol. 27, pp. 94-103. https://doi.org/10.1016/j.chieco.2013.09.001

7. Johnson, L.; Wandera, B.; Jensen, N. and Banerjee, R. (2018), "Competing Expectations in an Index-Based Livestock Insurance Project", The Journal of Development Studies, Vol. 55, No. 6, pp. 1221-1239. https://doi.org/10.1080/00220388.2018.1453603

8. Kaleem, A. and Ahmad, S. (2010), "Bankers' perception towards Bai Salam method for agriculture financing in Pakistan", Journal of Financial Services Marketing, Vol. 15, No. 3, pp. 215-227. https://doi.org/10.1057/fsm.2010.18

9. Kaleem, A. and Wajid, R. A. (2009), "Application of Islamic banking instrument (Bai Salam) for agriculture financing in Pakistan", British Food Journal, Vol. 111, No. 3, pp. 275-292. https://doi.org/10.1108/00070700910941471

10. Kassim, Z. A. M. (2013), "The Primary Insurance Models", in: Gonulal, S. O. (Ed.), Takaful and Mutual Insurance: Alternative Approaches to Managing Risks, Washington DC: World Bank, pp. 21-31.

11. Leading Edge (2011), Insurance products with a difference [Online] Available from: http://www.leadingedgeguides.com/guide-sudan-2016-shiekan-insurance/ [accessed on 30 March 2019].

12. Mahmood, N. R. (1991), "Takaful: The Islamic system of mutual insurance: The Malaysian experience", Arab Law Quarterly, Vol. 6, No. 3, 280-296. https://doi.org/10.2307/3381379

13. Mahul, O. and Stutley, C. J. (2010), Government Support to Agricultural Insurance: Challenges and Options for Developing Countries, Washington, D.C.: World Bank Group. https://doi.org/10.1596/978-0-8213-8217-2

14. Manap, A. S. H.; Siththi, F.; Long, S. and Muneeza, A. (2017), "Poverty Alleviation via Microfinance using the Concept of Mudharabah", International Journal of Management and Applied Research, Vol. 4, No. 3, pp. 166-178. https://doi.org/10.18646/2056.43.17-013

15. Maysami, R. C. and Williams, J. J. (2006), "Evidence on the relationship between Takaful insurance and fundamental perception of Islamic principles", Applied Financial Economics Letters, Vol. 2, No. 4, pp. 229-232. https://doi.org/10.1080/17446540500461778

16. Moh'd, I. S., Omar Mohammed, M. and Saiti, B. (2017), "The problems facing agricultural sector in Zanzibar and the prospects of Waqf-Muzar'ah-supply chain

International Journal of Management and Applied Research, 2019, Vol. 6, No. 4 
model: The case of clove industry", Humanomics, Vol. 33, No. 2, pp. 189-210. https://doi.org/10.1108/H-02-2017-0033

17. Oladokun, N. O., Larbani, M. and Mohammed, M. O. (2015), "The problems facing the agricultural sector in Nigeria and the prospect of Muzara'ah and supply chain model", Humanomics, Vol. 31, No. 1, pp. 18-36. https://doi.org/10.1108/H11-2012-0022

18. Putri, A. K.; Razia, R. and Muneeza, A. (2019), “The Potential of Bai Salam in Islamic Social Finance to Achieve United Nations' Sustainable Development Goals", International Journal of Management and Applied Research, Vol. 6, No. 3, pp. 142-153. https://doi.org/10.18646/2056.63.19-010

19. Sadler, M. P.; Alberto, M. A. ; Swann, S. A.; Vasileiou, I.; Baedeker, T.; Parizat, R.; Germer, L. A.; Mikulcak, F. (2016), Making climate finance work in agriculture, Washington, D.C.: World Bank Group. Available from: http://documents.worldbank.org/curated/en/986961467721999165/Makingclimate-finance-work-in-agriculture [Accessed on 5 April 2019].

20. Saiti, B., Afghan, M. and Noordin, N. H. (2018), "Financing agricultural activities in Afghanistan: a proposed salam-based crowdfunding structure", ISRA International Journal of Islamic Finance, Vol. 10, No. 1, pp. 52-61. https://doi.org/10.1108/IJIF-09-2017-0029

21. Sandelowski, M. (1995), "Sample size in qualitative research", Research in Nursing \& Health, Vol. 18, No. 2, pp. 179-183. https://doi.org/10.1002/nur.4770180211

22. Tropea, F. and Devuyst, P. (2016), Price volatility in agricultural markets: Risk management and other tools [Online] Available from: http://www.europarl.europa.eu/RegData/etudes/BRIE/2016/586609/EPRS_BRI(20 16)586609_EN.pdf [accessed on 30 April 2019].

23. World Bank (2018), Agricultural finance and agricultural Insurance, [Online] Available from: http://www.worldbank.org/en/topic/financialsector/brief/agriculture-finance [accessed on 30 March 2019].

24. Zaman, S, M. H. (1991), "Bay Salam: Principles and Practical Application", Islamic Studies, Vol. 30, No. 4, pp. 443-461.

International Journal of Management and Applied Research, 2019, Vol. 6, No. 4 